\title{
Use of Sewage Sludge as Raw Material in the Manufacture of Roofs
}

\author{
Durante Ingunza, Maria Del Pilar, Lima Andressa \\ Dantas \\ DepartmentofCivil Engineering. FederalUniversityof Rio \\ Grande do Norte, Campus Universitário, \\ Natal/RN, 59072-970, Brazil
}

\begin{abstract}
The present study verifies the possibility of incorporating sewage sludge in the production of ceramic mass for ceramic roof tiles. Domestic sewage sludge and clay from ceramic industries of the northeast region of Brazil were used. The raw materials were chemically and mineralogically characterized. Seven hundred and fifty tiles were manufactured using different concentrations of sludge $(2 \%$, $4 \%, 6 \%, 8 \%$ and $10 \%$ of sludge dry mass). The high amount of organic material $(\mathbf{7 1 \% )}$ ) from the sludge shows itself as being main factor on affecting the quality of roof tiles. The increased dosage of sludge implies a linear tendency of increased absorption and decreased load rupture on flexion. Results have shown the possibility of using nearly $4 \%$ of sludge (dry matter) on ceramic mass to manufacture roof tiles with no interference in its final product properties, in compliance with current international standards.
\end{abstract}

\section{Keywords-sewage sludge; raw material; roof manufacture}

\section{INTRODUCTION}

One of the greatest challenges of this century is the adequacy of technological progress to sustainable development programs, regarding material recycling and, more specifically, within the civil construction industry. In this context, in Brazil, researches have been developed to study the sewage sludge as a raw material for the civil construction industry [1-14].Internationally, early studies showing feasibility of recycling waste in the construction industry began in the 1980s, providing important information for future studies [15-33].

In northeast Brazilian region, incineration of sludge is not a common practice and generally, dry sludge are disposed in landfills. The aim of this research is to attempt another environmentally appropriated use for this kind of waste.

\section{EXPERIMENTAL PROCEDURES}

The raw materials used to obtain ceramic roof tiles were sludge, sand and clay. The sludge, from the drying beds of a Sewage Treatment Plant that treats domestic sewage, it's a non-hazardous and non-inert waste by the Brazilian standard [34], based on CFR-Title 40- Protection of environmental-Part 260-265 - Hazardous Waste Management. The roof tiles were produced in a ceramic industry of the area. In order to facilitate the research's applicability in real scale, roof tiles were thus manufactures following exactly the process of the ceramic company, modifying it only the partial replacement of clay by the sludge.

\author{
Nascimento Rubens Maribondo \\ Department of Material Engineering. Federal University \\ of RioGrande do Norte, Campus Universitário, \\ Natal/RN, 59072-970, Brazil
}

The experiment produced 740 units of roof tiles with sludge. The roof tiles produced have a colonial style, with standard dimensions: $48 \mathrm{~cm} \mathrm{x} 20 \mathrm{~cm} \times 15 \mathrm{~cm}$. The roof tiles' Merging Unit (MU), that is, the plasticity index of the mixture was in average $31.33 \%$. In order to facilitate the understanding of results, the research made an approximation of the dry mass sludge dosages to $2 \%, 4 \%$, $6 \%, 8 \%$ and $10 \%$ respectively, being those the previously intended dosages.

\section{RESULTS AND DISCUSSION}

\section{A. Characterization of Raw Materials.}

It is observed that the sludge used in the research shows granulometric characteristics similar to conventional raw materials (sand and clay). The values between 2 and $20 \mu \mathrm{m}$ are in the range for roof tiles production (20 to 50\%). However, the raw materials show predominance of particles larger than $20 \mu \mathrm{m}$, probably due to higher incidence of nonclay minerals, such as quartz. This can also be evidenced by the average diameter shown. The conventional raw materials consist predominantly of $\mathrm{SiO}_{2}$ (75\%), $\mathrm{Al}_{2} \mathrm{O}_{3}(15 \%)$ and $\mathrm{K}_{2} \mathrm{O}(4 \%)$. However, the sludge consists mainly of $\mathrm{SiO}_{2}$ (32\%), $\mathrm{CaO}(14 \%), \mathrm{Fe}_{2} \mathrm{O}_{3}(13 \%), \mathrm{SO}_{3}(13 \%)$ and $\mathrm{Al}_{2} \mathrm{O}_{3}$ (10\%).The mineralogical analysis carried out has concluded that conventional raw materials are comprised basically of three mineralogical phases: kaolinite, quartz and feldspars (albite and microcline). The sludge consists mainly of quartz and feldspars (anorthite).The sludge has, on average, $71 \%$ of organic matter, $84 \%$ of solids and 1.39 of real density.

\section{B. Characterization of produced roof tiles.}

The most limiting factor in setting the sludge dosage to incorporate into the mass of clay was the content of organic matter; because in some cases, it was visually found that its presence in significant amount (71\%) is responsible for conferring more porosity and consequently higher absorption and less resistance to the ceramic roof tiles.

All roof tiles with sludge lost mass when compared with the respective controls, due to the burning of organic matter. The addition of sludge into the conventional clay mass does not damage the extrusion of the roof tiles, because their moist of conformation (31.33\%) is within the recommended level for moulding extrusion.

\section{Water Absorption.}

It is seen a linear tendency in the increase of absorption with the dosage raise of sludge (Fig. 1), showing as a possible limiting factor in the incorporation of higher 
amounts in the clay mass. This aspect is seen even when considering different formulations of clay mass used by the company. Another important aspect to consider is the high loss on ignition of sludge used (71\%, on average), being the absorption influenced by its high value. If the sludge showed a lower content of organic matter, perhaps the problem of increased absorption was not that evident.

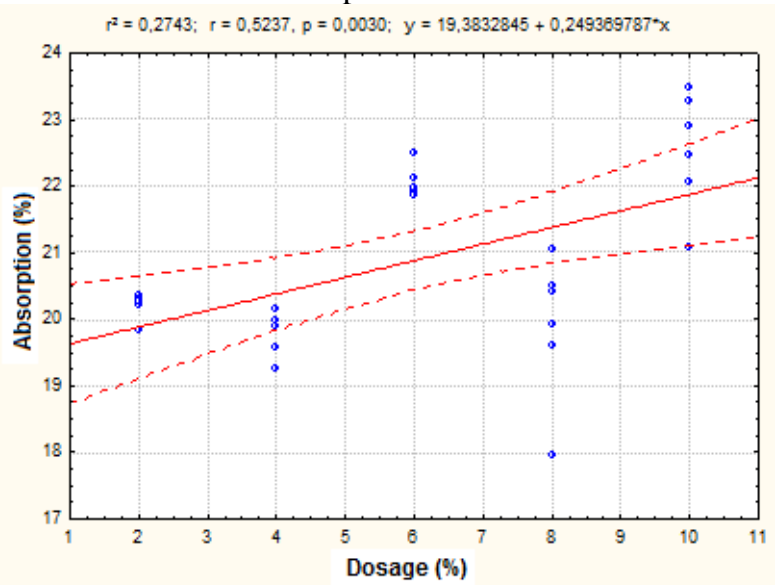

Fig.1. Correlation between the amount of sludge incorporated and the absorption of ceramic roof tiles.

\section{Flexural Rupture Strength.}

For all dosages, there is a reduction of rupture strength to flexion with the addition of sludge to clayey mass used by the company, comparing with their controls.

Observing Fig. 2, there is a linear tendency of decreasing flexural rupture strength with the raise of sludge dosage. There is a decrease on values of flexural rupture strength of the respective controls as they are raised (Fig. 3). It demonstrates that not only the increase of sludge has a significant influence on the values of reduced flexural rupture strength, but also their own raw materials applied by the company.

\section{E. Environmental Ricks.}

The sludge used in the research is domestic sewage sludge, classified as non-hazardous and non-inert waste by the Brazilian standard (NBR 10004-ABNT, 2004), and based on CFR-Title 40- Protection of environmental-Part 260-265 - Hazardous Waste Management.

Due to high levels of $\mathrm{SO}_{3}$ present in the sludge, possible environmental risks in the burning process of roof tiles must be evaluated. Some authors have reported average $\mathrm{SO}_{2}$ emissions in ceramic products with sludge to be considerably below to what is required by legislation [28]. Nevertheless, in case of sludge incorporation as raw material in full scale, measurements of the levels of emission must be performed, in accordance with current standards.

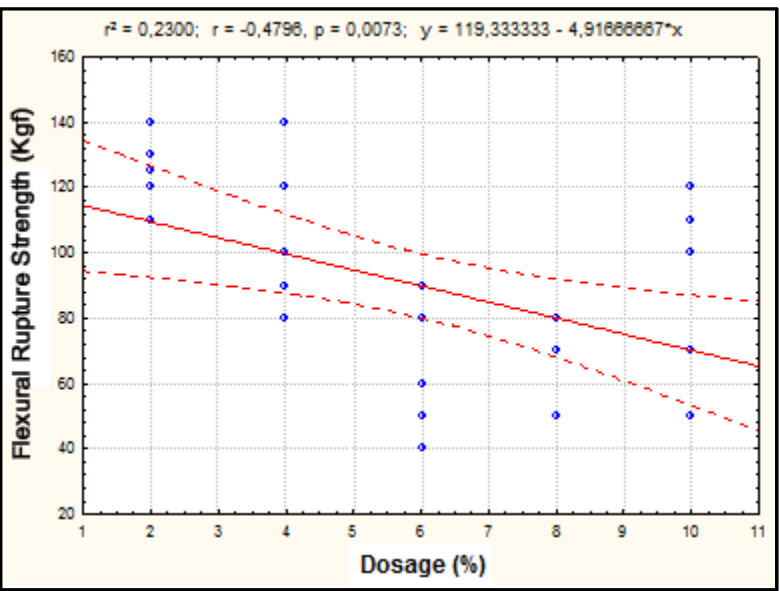

Fig. 2.Correlation between sludge dosage applied and the flexural rupture strength of roofs tiles.

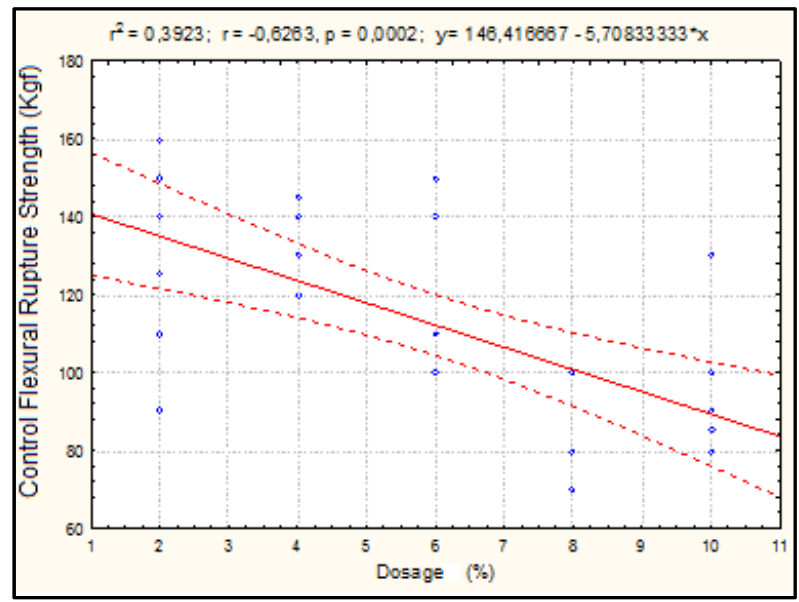

Fig. 3.Correlation between the control roof tiles of the respective sludge dosage applied and their flexural rupture strength.

\section{CONCLUSIONS}

It is possible to use around $4 \%$ of sludge (dry matter) in ceramic mass to manufacture roof tiles, without interfering in the properties of the final product, regarding the compliance with the current standard.

The high amount of organic material (71\%) present in the sludge is shown as a limiting factor in the incorporation of sludge in ceramic mass, compromising the quality of roof tiles, once they visually show porosity, in addition to a higher absorption of water and lower rupture load, when compared to the controls.

The increased dosage of sludge implies in a linear tendency of increased absorption and a reduction in flexural rupture strength. There is a decrease in flexural rupture strength of the controls. This demonstrates that not only the sludge has a significant influence on the values of flexural rupture strength as well as their own raw materials used by the company. 


\section{REFERENCES}

[1] Moreira, A. H., Oliveira , R. M. ; Lima , P. D. S. Effect of the addition of sewage sludge from textile industry in the properties of construction materials, Cerâmica,47 (303) , pp.158-162, 2001.

[2] Nuvolari, A. Inertization of sewage sludge in clay brick: Technological and environmental aspects, 238 p. Thesis (Ph.D.). Faculty of Civil Engineering, University of Campinas, São Paulo, Brazil, 2002.

[3] Teixeira, S. R.; Alves Souza, S.; Rodrigues Souza, N.; Job, A. E.; Gomes, H. M.; Heitzmann Neto, J. F. Characterization of waste water treatment plants (WTP) and wastewater (WWTP) and the study of the feasibility of its use in the ceramic industry. Proceedings of the XXVIIIInter-American Association of Sanitary and EnvironmentalEngineeringCongress, Tegucigalpa, 1-4 October, pp 10-20.Honduras, 2013.

[4] Fontes, C. M. A. Potential of ash sludge from sewage treatment plants as supplementary material for Portland cement concrete, pp 120 . Thesis (Master).Post-graduation Programof Engineering, Federal University of Rio de Janeiro - COPPE, Rio de Janeiro, Brazil, 2003.

[5] Santos, A. D. Study of the possibilities of recycling of sewage wastes in the metropolitan region of São Paulo. Pp 265.Thesis (Master). Department of Civil Construction Engineering, Polytechnic School, University of São Paulo, São Paulo, Brazil, 2003.

[6] Araújo, F. S. D., Leite, J. Y. P., Araújo, A. L. C., Ingunza, M.P. D. Characterization of raw materials for reuse of sludge sewage in ceramics products.Proceedings of the 23 BrazilianCongress of Sanitary and EnvironmentalEngineering, Campo Grande, pp 1-10. MS, Brazil, 2005.

[7] Romano Neto, R.; Santos, E. F.; Izidoro, G.; Vieira, P. C.; Schneider, I. A. H. Use of sewage sludge of mining in ceramic materials. Proceedings of XXX Brazilian Meeting of Mining Treatment and Extrative Metallurgy, Natal, pp 10-20. Brazil,2005.

[8] Santos , I. M. G., Silva , J. M.,; Trinity , M. F. S., Soledade , L. E. B. , Souza , A. G. , Paskocimas , C. A., Long , E. Effect of the addition of wastes in the decrease of black core phenomenon in red ceramic. Cerâmica, 51, 144-150, 2005.

[9] Ingunza, M. P. D., Tinôco, J. D., Lima, A. D., Santos Junior, O. F., Nascimento, R.M. Characterization of sewage sludge to reuse it in ceramic industry. Proceedings of the XXX Inter-American Association of Sanitary and EnvironmentalEngineeringCongress, Punta del Este, pp 1-10. Punta del Este, Uruguay, 2006a.

[10] Ingunza, M. P. D., Tinôco, J. D.; Nascimento, R. M., Araújo, A. L. C., Brito, L. P.; Lima, A. D. Use of sewage sludge as a raw material in the manufacture of bricks in Açu/RN / Brazil. Proceedings of the $X X X$ Inter-American Association of Sanitary and EnvironmentalEngineeringCongress Punta del Este, pp 20-30. Punta del Este, Uruguay, 2006b.

[11] Ingunza, M. P. D., Andreoli, C. V., Nascimento, R. M.; Tinôco, J. D., Hoppen, C., Pegorini, E. S. Use of sanitationwaste in theManufacturing of red ceramic, pp. 283-359. In: Andreoli, C.A., Alternativas de uso de resíduos do saneamento (Alternative use ofsanitationwaste). ABES, Rio de Janeiro, Brazil, 2006c.

[12] Ingunza, M.P.D., Duarte, A.L.D., Nascimento, R.M.Use of sewage sludge as raw material in the manufacture of soft-Mud Bricks, Journal of Materials in civil Engineering, 23(6), 852-856, 2011.

[13] Ingunza, M.P.D., Santos Junior, O.F., Medeiros, S.A. Sewage sludge as raw-material in asphalt mixtures, Advanced Materials, 664, 638643, 2013a.

[14] Ingunza, P.D., Lima, A.D., Araujo, A.C. Use of septic tank sludge as raw material in the manufacture of bricks. Advanced Materials.712715, 921-924, 2013b.

[15] Alleman, J. E., \& Berman, N. A. Constructive Sludge Management: Biobrick”, Journal of Environmental Engineering, 110(2), 301-311, 1984.
[16] Tay, J. H. "Sludge and incinerator residue as building and construction materials", Proceedings from Interclean '84 Conference,Singapore, pp 252-261, 1984.

[17] Slim, J. A., Wakefield, R. W. The utilization of sewage sludge in the manufacture of clay bricks. Water SA, 17 (3), 1991.

[18] Anderson, M., Skerralt, R.G.,Thomas, J.P. and Clay S.D Case study involving using fluidised bed incinerator sludge ash as a partial clay substitute in brick manufacture. Water Science Technology, 34 (3-4), 507-515, 1996.

[19] Cusidó, J.A., Devant, M., Celebrovsky, M., Riba, J. e Arteaga, F. Ecobrick: A new ceramic material for solar buildings. Special Issue World Renewable Energy Congress Renewable Energy, Energy Efficiency and the Environment.Renewable Energy, 8(1-4), 327 330, 1996.

[20] Dominguez, E. A., \& Ullman, R. Ecological bricks made with clays and steel dust pollutants, Applied Clay Science, 11 , 237-249, 1996.

21] Okuno, N., Takahashi, S.Full scale application of manufacturing bricks from sewage.Water Science and Technology.36 (11), 243-250, 1997.

[22] Tay, J.-H. and Show, K.-Y. Resource recovery of sludge as a building and construction material - A future trend in sludge management, Wat.Sci. Tech. 36(11), 259-266, 1997.

[23] Wiebusch, B.; Seyfried, C.F.Utilization of sewage sludge ashes in the brick and tile industry, Water Science and Technology, 36 (11), 251258, 1997.

[24] Stone, R. J.; Ekwue, E. I.; Clarke, R. O. Engineering Properties of Sewage Sludge in Trinidad. Journal of Agricultural Engineering Research, 70, 221-230, 1998.

[25] Onaka, T. Sewage can make Portland cement: a new technology for ultimate reuse of sewage sludge, Water Science \& Technology, 41, 93-98, 2000.

[26] Lin, D.-F., \&Weng, C.-H. "Use of Sewage Sludge Ash as Brick Material, Journal of Environmental Engineering, Vol.127, No. 10, 2001.

[27] Anderson, M. Encouraging prospects for recycling incinerated sewage sludge ash into clay based building products. J. Chem. Technol. Biotech., 77, 352-360, 2002.

[28] Cusido, J. A.; Cremades, L. V.; González, M.Gaseous emissions from ceramics manufactured with urban sewage sludge during firing processes. Waste Management, 23, 273-280, 2003.

[29] Weng, Chih-Huang; Lin, Deng-Fong; Chiang, Pen-Chi. Utilization of sludge as brick materials.Advances in Environmental Research, 7,679-685, 2003.

[30] Liew, A. G., Idris S, A., Samad, A. A., Wong, C. H. K., Jaafar, M. S., Baki, A. M.Reusability of sewage sludge in clay bricks.J Mater Cycles Waste Manag, 6, pp. 41-47, 2004.

[31] Okuno, N., Ishikawa, Y., Shimizu, A., Yoshida, M. Utilization of sludge in building material. Water, science and technology, 49 (10), 225-232, 2004.

[32] Jordán, M.M. Almendro-Candel, M. Romero, M. Rincón, J. Application of sewage sludge in the manufacturing of ceramic tile bodies. Applied Clay Science, 30 (2005) [3-4], 219-224; DOI: 10.1016/j.clay.2005.05.001, 2005.

[33] Cernec, F. Zule, J., Moze, A., Ivanus, A. Chemical and microbiological stability of waste sludge from paper industry intended for brick production. Waste Management \& Research, 23, 106-112, 2005.

[34] ABNT NBR 10:004-10:007- Brazilian Standard test methods for solid waste, 2004. 